\title{
Why not use the Easybreath snorkeling mask to prevent COVID-19 transmission during endoscopy procedures when FFP2 are lacking?
}

Coronavirus 2019 disease (COVID-19) is spreading all over the world. Endoscopy unit personnel are especially exposed to respiratory secretions (in aerosol-generating procedures) and feces [1].

Chinese endoscopy units [2,3] and endoscopy societies recommend the use of personal protective equipment, especially for procedures on patients with a highly suspected or confirmed COVID-19 infection.

Recently, Repici et al. published recommendations to prevent and control COVID-19 transmission during endoscopic examinations [4]. However, many countries are affected by a shortage of necessary equipment, especially N95 or FFP2 masks.

A few years ago in Europe, a sports equipment company (Decathlon, Lille, France) developed a snorkeling mask called "Easybreath" ( $\triangleright$ Fig. 1), which has recently been used as a protective mask in many hospitals. The company recently announced it would cease broad distribution of these masks to make them available for European hospitals.

In Tahiti's endoscopy units, where FFP2 masks must be saved, we describe the possible use of the Easybreath mask as a protective device to replace FFP2 and FFP3 masks, goggles, and face shields. Pending $3 \mathrm{D}$ printing production of filters adaptable to the mask proposed by small Italian companies (Isinnova, Val Trompia), we used a surgical mask at the top of the snorkel to filter the air ( Video 1 ). This snorkeling mask has the advantage of being washable, disinfectable, and reusable. This single unit provides fullface protection for endoscopy staff and appears to effectively safeguard the eyes, mouth, and nose from contact with the virus.
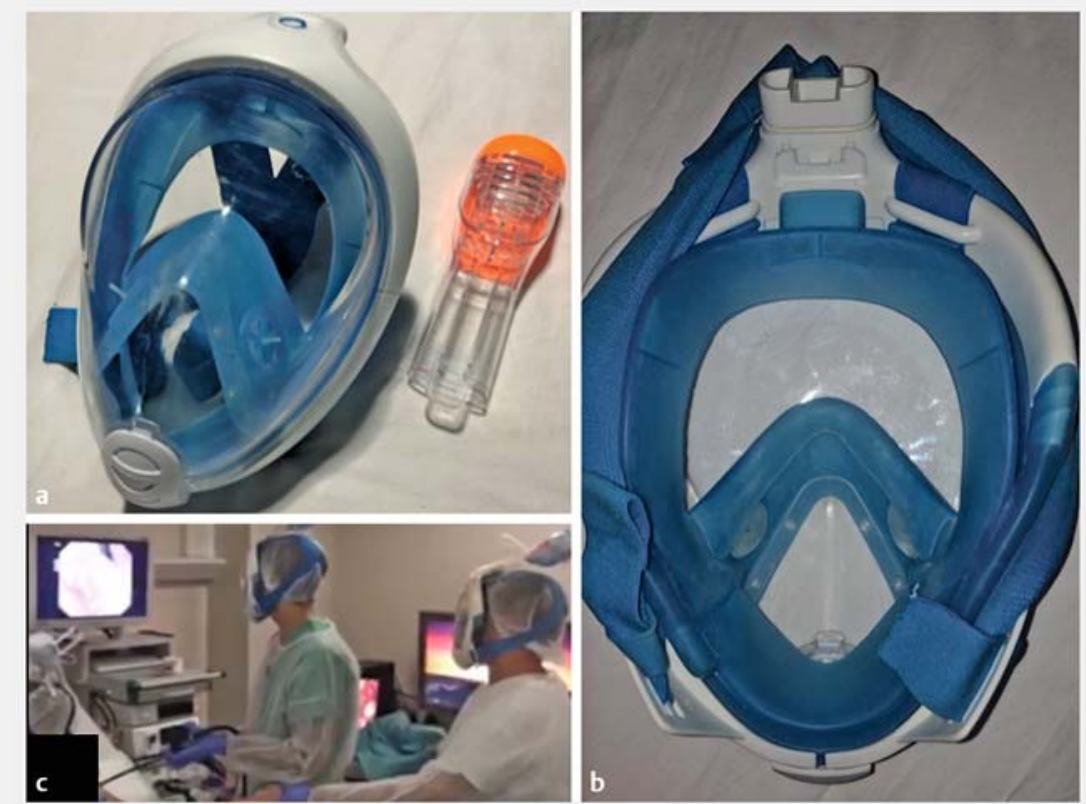

- Fig. 1 Aspect of the mask. a External aspect. b Internal aspect. c Aspect during endoscopy procedure.

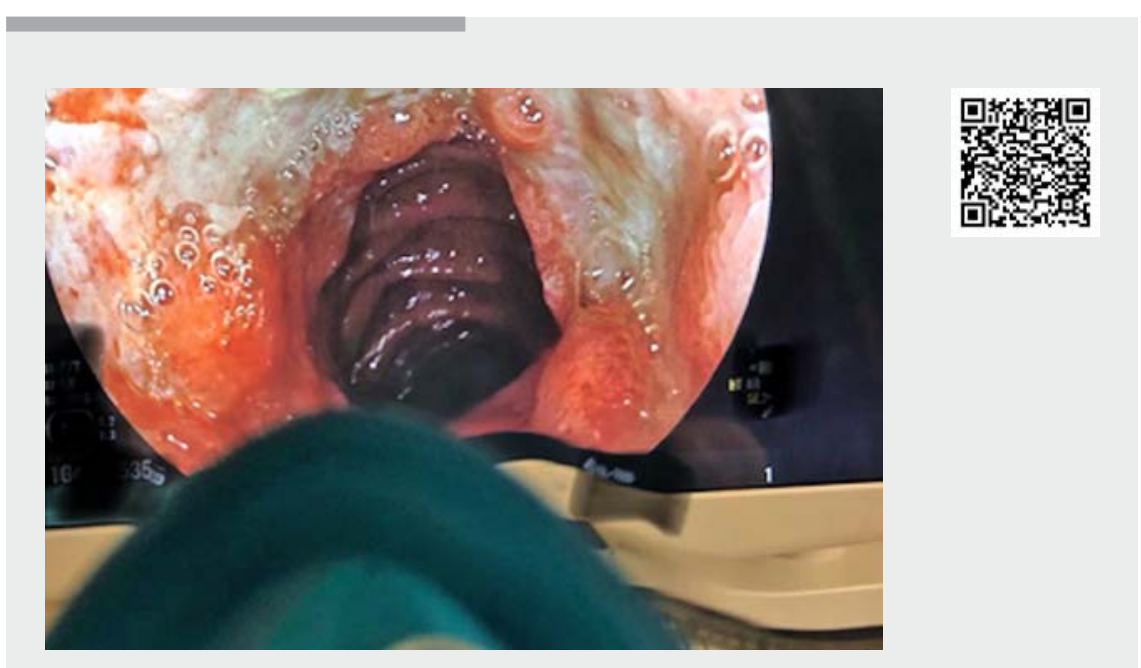

Video 1 Use of an Easybreath snorkeling mask to prevent COVID-19 transmission during endoscopy procedures. 

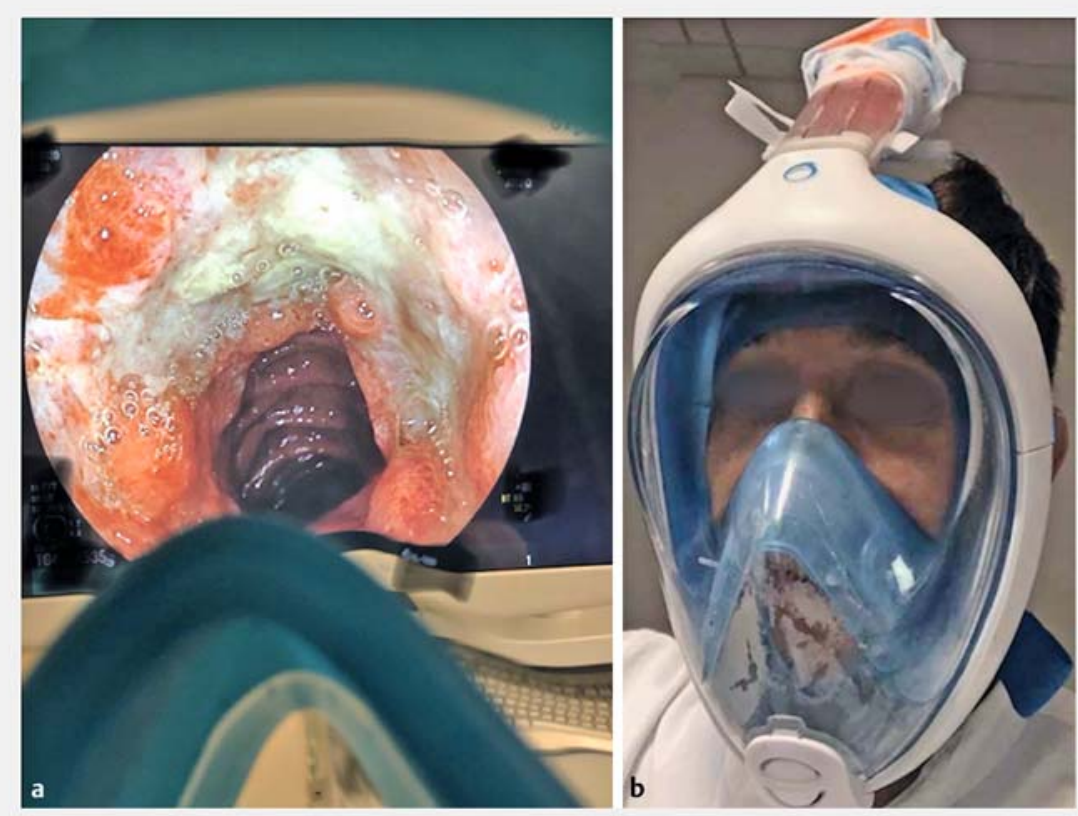

- Fig. 2 Easybreath mask. a Visibility of the endoscopy screen through the mask. b View of the endoscopist with the mask with a filter added on the snorkel.
In our experience, the endoscopic examination quality was not altered by reduced visibility ( $>$ Fig.2a). This product is particularly efficient at preventing fogging ( $>$ Fig. 2 b).

While the mask's affect may elicit ridicule, ridicule does not kill - not as much as COVID-19.

Endoscopy_UCTN_Code_TTT_1AO_2AN

\section{Competing interests}

The authors declare that they have no conflict of interest.

\section{The authors}

Jérôme Rivory ${ }^{1,2}$, Éric Beaugendre ${ }^{1}$, Claire Yvon ${ }^{1}$, Fréderic Ploteau ${ }^{1}$, Bertrand Condat ${ }^{1}$, Florian Rostain ${ }^{2}$, Mathieu Pioche ${ }^{2,3}$

1 Department of Endoscopy and Gastroenterology, French Polynesia Hospital, Papeete, French Polynesia

2 Department of Endoscopy and Gastroenterology, Pavillon L, Edouard Herriot Hospital, Lyon, France

3 Inserm U1032 LabTau, Lyon, France

\section{Corresponding author}

\section{Jérôme Rivory, MD}

Endoscopy Unit, Digestive Disease Department, Pavillon L, Edouard Herriot Hospital, 69437 Lyon Cedex, France Fax: +33-4-72110147

Jerome.rivory@chu-lyon.fr

[1] Gu J, Han B, Wang J. COVID-19: Gastrointestinal manifestations and potential fecal-oral transmission. Gastroenterology 2020. doi:10.1053/j.gastro.2020.02.054

[2] Ang TL. Gastrointestinal endoscopy during COVID-19 pandemic. J Gastroenterol Hepatol 2020. doi:10.1111/jgh.15048

[3] Zhang Y, Zhang X, Liu L et al. Suggestions for infection prevention and control in digestive endoscopy during current 2019-nCoV pneumonia outbreak in Wuhan, Hubei province, China. Endoscopy 2020; 52: 312-314

[4] Repici A, Maselli R, Colombo M et al. Coronavirus (COVID-19) outbreak: what the department of endoscopy should know. Gastrointest Endosc 2020. doi:10.1016/j. gie.2020.03.019

\section{Bibliography}

DOI https://doi.org/10.1055/a-1178-9125

Published online: 29.5.2020

Endoscopy 2020; 52: E306-E307

(c) Georg Thieme Verlag KG

Stuttgart · New York

ISSN 0013-726X

\section{ENDOSCOPY E-VIDEOS}

https://eref.thieme.de/e-videos

回迢 Endoscopy E-Videos is a free access online section, reporting 回: on interesting cases and new techniques in gastroenterological endoscopy. All papers include a high quality video and all contributions are freely accessible online.

This section has its own submission website at https://mc.manuscriptcentral.com/e-videos 